\title{
FORESTRY WORK-RELATED INJURIES \\ IN FOREST ESTATE „SREMSKA MITROVICA“ \\ IN SERBIA
}

\author{
OZLJEDE PRI ŠUMSKOM RADU U ŠUMSKOME \\ GOSPODARSTVU „SREMSKA MITROVICA“ U SRBIJI
}

\author{
Milorad DANILOVIĆ ${ }^{1}$, Slavica ANTONIĆ ${ }^{2}$, Zoran ĐORĐEVIĆ ${ }^{3}$, Pajo VOJVODIĆ4
}

\begin{abstract}
Sažetak
In most developed countries forestry is among the occupations with the highest rate of occupational injuries. The aim of this study was to determine the frequency and main causes of occupational injuries in Serbian forestry. The data were collected in the area managed by the Forest estate (FE) "Sremska Mitrovica" for the period from $1^{\text {st }}$ January 2008 to $31^{\text {st }}$ December 2012. The analyses involved workers engaged in different forest work operations (logger, manual loader, silvicultural worker and driver). The data analysis showed that light injuries account for $95 \%$ of all occupational injuries, while severe occupational injuries account for $5 \%$ of them. In the analyzed period there were no fatal injuries. The percentage of injuries in the total number of workers is $12 \%$. The most commonly injured workers were loggers (68\%). According to the analysis, every fourth logger was injured, and the largest number of them were injured once ( 99 workers). Twenty-six of them were injured twice during the same period and 9 three or more times. The average logger age was 38.8 , and their average length of service was 16 years. The largest number of logger injuries occurred in March and May, on Mondays (almost 1/3 of injuries) in the period from 10 to $11 \mathrm{AM}$, and the most frequently injured body parts were the legs (38\%) and arms (35\%). The most common cause of injury is the blow of a branch (35\%).
\end{abstract}

KEY WORDS: forest utilization, occupational injuries, logger injuries

\section{INTRODUCTION}

\section{UVOD}

Public companies manage state forests of the Republic of Serbia (about $43 \%$ of the total forest area) (Medarević et al., 2008). In the Public enterprise (PE) „Srbijašume“ private companies are hired for forest utilization operations. In the Public enterprise (PE) „Vojvodinašume“ most of the timber volume (55-60\%) is logged by the company's own labour force, while the rest is logged by hired private companies. From the total volume of wood felled in the forests of Serbia, about $98.5 \%$ is felled with a chainsaw, and about $1.5 \%$ with a harvester (Danilović and Cuprić, 2011). The most common organizational form of work in the operations of logging and assortment processing is $1 \mathrm{C}+1 \mathrm{~A}$ (1 chainsaw operator +1 assistant). 
Two thirds of injuries are concentrated in four high-risk branches (viz. agriculture, construction, manufacturing and transport) (Macedo and Silva, 2005). The accident rate in forestry is significantly higher than in other sectors considered to be of high risk: e.g. the fatal accident rate in the United States forestry was 19 times higher than in other sectors, but also 11.5 times greater than in the New Zealand forest sector, revealing that forest work is the most dangerous, with loggers being the most exposed (Peters, 1991; Bell, 2002, Lefort et al., 2003, Albizu-Urionabarrenetxea et al., 2013). In Spain, the incident rate of all other sectors was 3 to 4 times lower than that of forestry (Cabeças, 2007). In Australian forestry, injuries were 2 to more than 3 times greater than in the rest of industries (Driscol et al., 1995). Fatal accidents rates in Germany were 3 times higher in the forestry sector than in construction, and twice as high as in agriculture. (AlbienUrionabarrenetxea et al. 2013).

Occupational injuries are affected by many factors (operating conditions, work organization etc.) Martinić (1999) listed working operation carried out against safety rules and irregular work performance as the most common reason for injuries of workers in Croatian forests.

Tree fellers have the most dangerous job in the logging industry (Occupational Safety and Health Administration [OSHA], 2000). Presumably, if machinery is used to harvest trees, the person operating the equipment will be protected by the cab of the machine, thus reducing the number of injuries caused by a falling object (Bell, 2002).

The number of occupational injuries in Serbia has steadily increased until the eighties, which was followed by a period of stagnation until 1985 and then a decline in the number of injuries (Aranđelović and Jovanović, 2009). The reason for this is probably a decrease in production volume and sporadically reported violations. At the same time, the number of fatal injuries was not significantly reduced. Most of the injured workers were recorded in forestry, which was followed by water management, construction and agriculture (Aranđelović and Jovanović, 2009).

Generally speaking, so far there have been no serious analyses of occupational injuries in Serbian forestry. This is confirmed by the fact that ILO and OSHA reports do not contain any data on Serbia. We were unable to obtain data on the entire territory of the Republic from the Statistical Office of the Republic of Serbia for the purpose of this study. However, the data on the territory of the FE „Sremska Mitrovica“ were provided by the PE „Vojvodinašume“. The Forest estate (FE) „Sremska Mitrovica“ as one of four forest estates within the PE „Vojvodinašume" has the largest timber volume of all of them. The intended felling volume in this FE is logged using the estate's own resources and labour force, with most workers being permanently employed.
The aim of this study is to determine the frequency of injuries and their causes. In addition, the goal is to estimate the correlation between worker performance and the frequency of injuries.

The main hypothesis in this paper is that occupational injuries are in correlation with worker performance.

\section{RESEARCH OBJECT OBJEKT ISTRAŽIVANJA}

The data for this study were collected in the territory of 5 work units located within the FE Sremska Mitrovica, as one of the four forest estates within the PE „Vojvodinašume“ in the Republic of Serbia: Forest administration (FA) Klenak (hereinafter referred to as WU1), FA Kupinovo (WU2), FA Morović (WU3), FA Višnjićevo (WU4) and Forest Machinery Morović (WU5). This forest estate (Figure 1) was selected as the research location because the entire logging and assortment processing in its territory are performed by engaging the FE's own resources and labour force.

All five work units of this forest estate are characterized by a flat terrain and average altitudes of below $100 \mathrm{~m}$, and

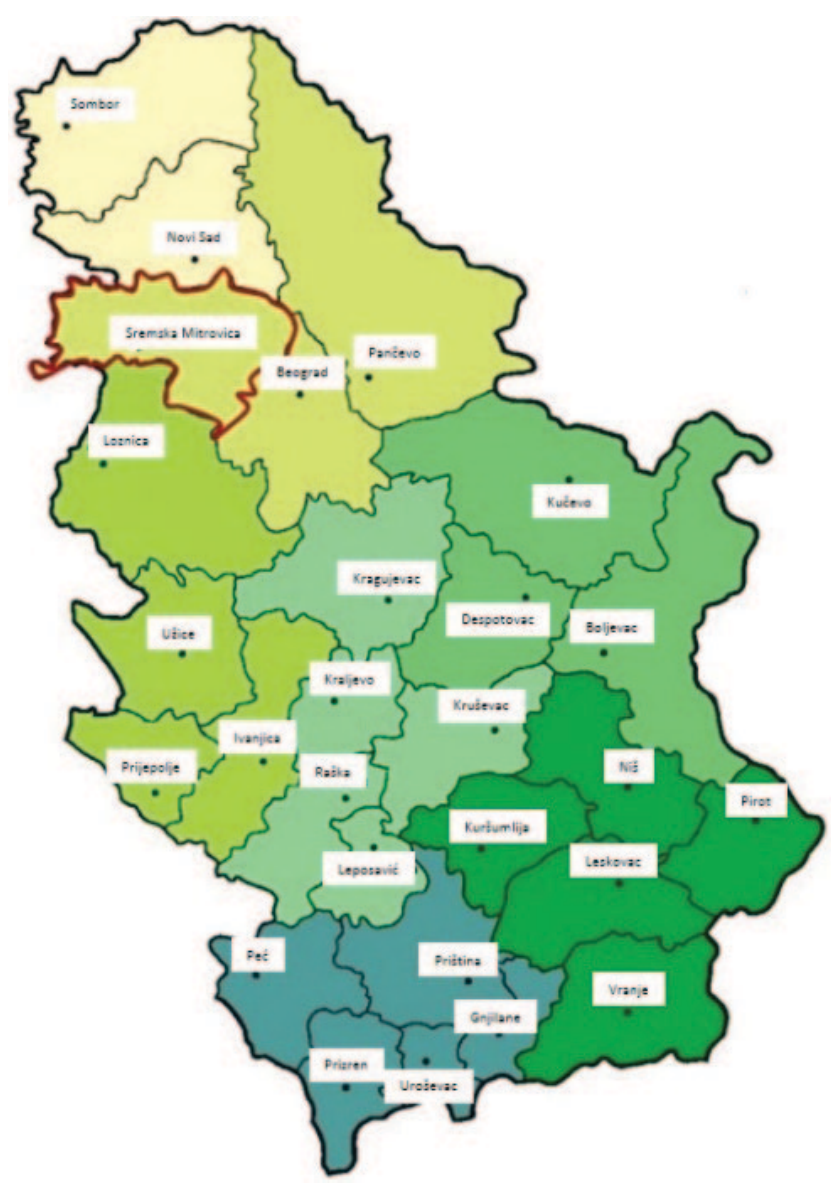

Figure 1. Forest estates in the territory of Serbia (borders of the FE "Sremska Mitrovica are marked in red“)

Slika 1. Šumska gospodarstva na području Srbije (crvenom bojom označene su granice ŠG „Sremska Mitrovica”) 
Table 1. Number of workers by work units, years and workplaces

Tablica 1: Broj radnika po radnim jedinicama, godinama i radnom mjestu

\begin{tabular}{|c|c|c|c|c|c|c|c|c|c|c|c|c|c|c|c|c|c|c|c|c|}
\hline \multirow{3}{*}{$\begin{array}{l}\text { WORK } \\
\text { UNITS } \\
\text { RADNE } \\
\text { JEDINICE }\end{array}$} & \multicolumn{5}{|c|}{$\begin{array}{l}\text { Logger } \\
\text { Sjekač }\end{array}$} & \multicolumn{5}{|c|}{$\begin{array}{l}\text { Manual loader - Utovarač } \\
\text { prostornog drveta (ručno) }\end{array}$} & \multicolumn{5}{|c|}{$\begin{array}{l}\text { Silvicultural worker } \\
\text { Šumski radnik }\end{array}$} & \multicolumn{5}{|c|}{$\begin{array}{l}\text { Drivers } \\
\text { Vozači }\end{array}$} \\
\hline & \multicolumn{20}{|c|}{ Year-Godina } \\
\hline & 2008 & 2009 & 2010 & 2011 & 2012 & 2008 & 2009 & 2010 & 2011 & 2012 & 2008 & 2009 & 2010 & 2011 & 2012 & 2008 & 2009 & 2010 & 2011 & 2012 \\
\hline WU1 - RJ1 & 25 & 23 & 24 & 25 & 26 & - & - & - & - & - & 34 & 34 & 34 & 34 & 30 & - & - & 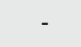 & . & - \\
\hline WU2 - RJ2 & 20 & 17 & 15 & 16 & 18 & 3 & 3 & 4 & 4 & 6 & 32 & 32 & 28 & 27 & 24 & - & - & - & 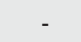 & - \\
\hline WU3 - RJ3 & 32 & 28 & 30 & 30 & 32 & 7 & 8 & 10 & 11 & 11 & 32 & 25 & 27 & 29 & 27 & - & - & - & - & - \\
\hline WU4 - RJ4 & 28 & 24 & 25 & 25 & 29 & 6 & 6 & 8 & 9 & 9 & 34 & 34 & 33 & 32 & 29 & - & - & - & - & - \\
\hline WU5 - RJ5 & - & - & - & - & - & - & - & - & - & - & - & - & - & - & - & 71 & 68 & 64 & 64 & 63 \\
\hline Sum - Suma & 105 & 93 & 94 & 96 & 105 & 15 & 17 & 22 & 24 & 26 & 132 & 125 & 122 & 122 & 110 & 71 & 68 & 64 & 64 & 63 \\
\hline
\end{tabular}

Euro-American poplar, pedunculate oak and ash as the main species. There are no major differences in the characteristics of the terrain and mode of work among these work units. However, there are differences in the felling volume and (softwood and hardwood) tree species that cover these surfaces. The annual felling volume of the forest estate is about $200000.00 \mathrm{~m}^{3}$ (about 52\% accounts for pedunculate oak and $30 \%$ for Euro-American poplar). Table 1 shows the total number of workers engaged in forest utilization operations in the period when the survey was conducted (20082012) by work units, years and workplaces.

Loggers were engaged in the operations of logging and assortment processing. Manual loaders were engaged in the loading and unloading of stacked wood. Silvicultural workers worked on silvicultural operations, while drivers drove tractors and trucks.

\section{MATERIALS AND METHODS MATERIJALI I METODE}

Each of the work-related injuries was recorded immediately after occurrence. The injury was recorded by the occupational medical service, i.e. a doctor who received the worker and examined the injury. The classification of injuries was performed according to the International Classification of Diseases and Related Health Problems, and the code list of diseases was taken from the paragraph „external causes of morbidity and mortality (V01-Y98)“.

After each recorded work-related injury, occupational medical service would send a report on medical examination of the injured worker to the Republic Labor Inspection, the Ministry of Interior and the clerk of occupational safety in the work unit where the worker was employed. From the report on medical examination of the employee, the data would be entered into a special record in each work unit and then sent for archiving to the head office and the person in charge of safety and health at work in the forest management unit. The following information were entered in the records: the name and surname of the injured worker, a description of the event, the injured body part, the type of injury and the cause of injury. For the purpose of this study, data on the age, length of service and performance of loggers at the time of injury were subsequently submitted. The assessment of the type of injury was performed by the doctor who first examined the worker. Light injury is considered an injury without serious consequences for the injured. On the other hand, severe injuries cause permanent consequences for the injured. There are three subdegrees of the severe injury type, including 1) severe bodily injury (no other attributes, the so-called regular severe injury), 2) particularly severe bodily injury, especially severe bodily injury with the loss of important organs, which is life threatening or causes mutilation; 3) fatal severe bodily injury.

Workers employed in forest utilization operations are permanently employed and work full-time for a period of 8 hours, i.e. from 6 to $14 \mathrm{~h}$ in summer and from 7 to $15 \mathrm{~h}$ in winter, with the right to a 30-minute break. Workers work according to a norm predetermined on a monthly basis, so that they are not paid overtime.

Regarding professional training, the forest estate provides loggers with a month-long course (theoretical classes) and two months of practical training, in which a future logger performs logging with the help of a more experienced colleague (mentor). Upon successful completion of the training, the worker receives a certificate of recognition of professional qualifications, serving as an internal proof. All workers have adequate equipment, and according to the „Law on Safety and Health at Work“ („Official Gazette of RS“, no. 101/2005) i.e. the „Regulations on previous and periodical medical examinations of employees at workplaces with increased risk" all workers are required to have a recurrent annual medical examination, carried out by an occupational medical service.

\section{RESULTS}

\section{REZULTATI}

On the basis of the analyzed number of occupational injuries in the 2000-2012 period, it was found that the largest number of occupational injuries were recorded among workers engaged as loggers (Figure 2). 


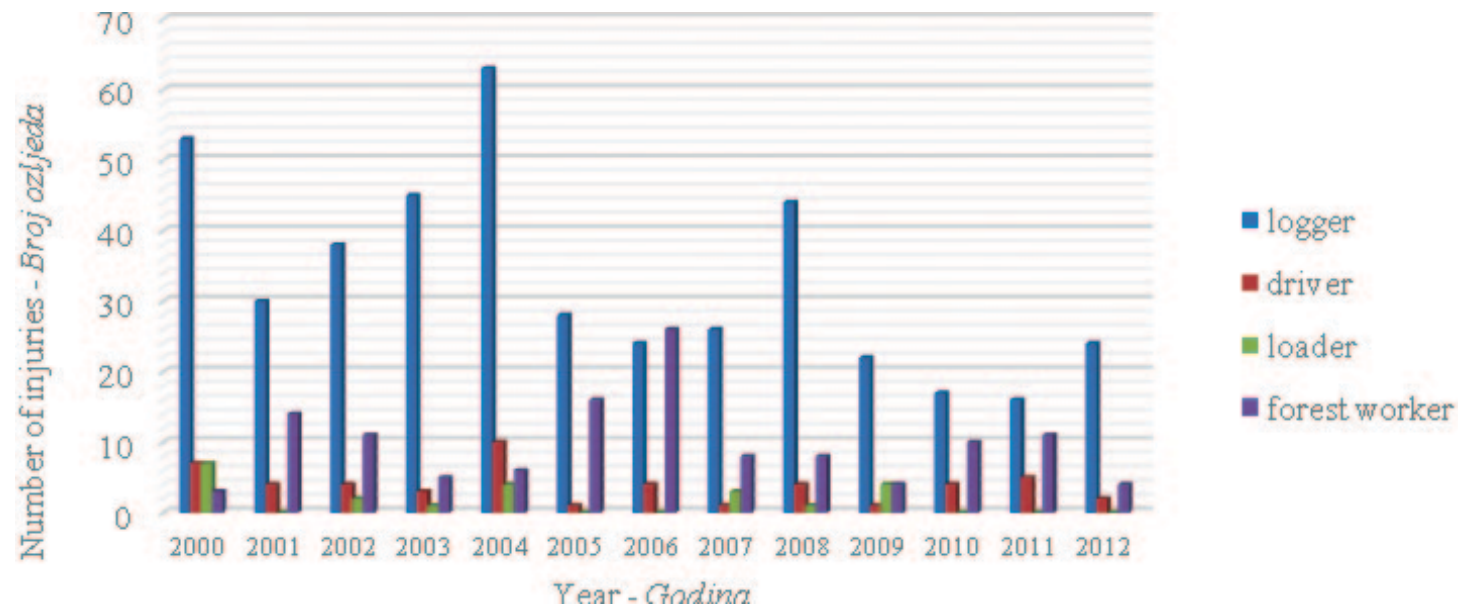

Figure 2: Number of injuries by years and type of work performed Slika 2: Broj ozljeda po godinama i vrsti posla koje su radnici obavljali

Due to incomplete data, further analyses included only a five-year period (01.01.2008.-31.12.2012.).

The total number of annually employed workers in forest utilization operations ranged from 302 (in 2010) to 323 (in 2008). The largest number of workers were employed in silvicultural operations (Table 1).

The total number of injuries recorded in the 2008-2012 period was 181, of which 172 light injuries, while 9 injuries were categorized as severe bodily injuries. All injured workers were men. There were no fatal injuries during this period. The percentage of injuries in the total number of workers is $12 \%$. Out of the total number of injured workers, the largest share (68\%) are loggers, which is followed by silvicultural workers $(20 \%)$, tractor drivers $(8 \%)$, manual loaders (3\%) and truck drivers (1\%) (Table 2). The largest number of injuries occurred in the territory of WU4 (Figure 3).

The largest number of injuries occurred in 2008 during logging operations, as much as $77 \%$ of the total number of injured workers that year (Table 2).
Injured loggers account for $25 \%$ of the total number of loggers. Due to the percentages of injured workers, further analyses included only those workers who worked as loggers. The average number of working days of these workers was 160 , while the average number of norm days (days needed to fulfill the norm) was 193 .

Out of the total number of injured workers during the 2008-2012 period, the majority were injured once $(99 \mathrm{em}$ ployees). In the same period, 26 workers were injured twice and 9 employees were injured three or more times. The largest number of injuries was registered in the territory of WU4 where, for example in 2008, out of the total of 28 workers engaged in logging and assortment processing, almost one half of workers were injured at least once during that year.

The most commonly injured workers were loggers aged between 30 and 40 (Figure 4), i.e. workers with between 15 and 20 years of service (Figure 5). The average worker age was 38.8 and the average length of service was 16 years.

Table 2: Number of workers and number of injured workers by years Tablica 2: Broj radnika i broj ozlijeđenih radnika po godinama

\begin{tabular}{|c|c|c|c|c|c|c|c|c|c|c|}
\hline \multirow[b]{2}{*}{ 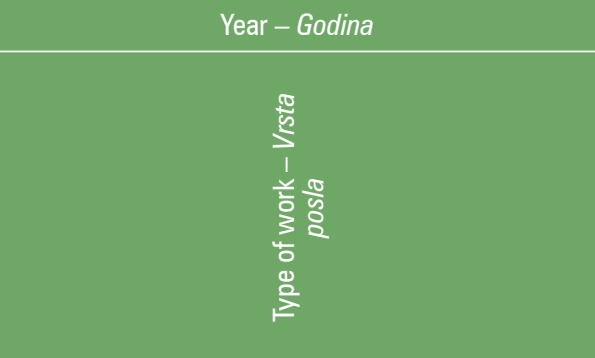 } & \multicolumn{2}{|c|}{2008} & \multicolumn{2}{|c|}{2009} & \multicolumn{2}{|c|}{2010} & \multicolumn{2}{|c|}{2011} & \multicolumn{2}{|c|}{2012} \\
\hline & 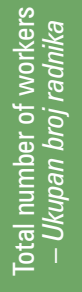 & 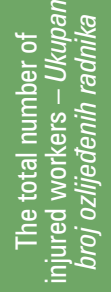 & 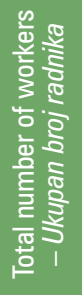 & 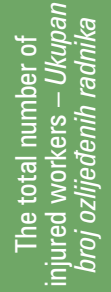 & 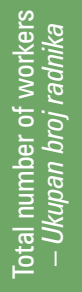 & 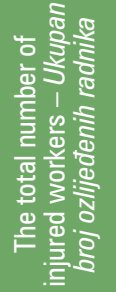 & 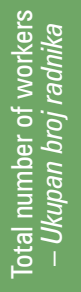 & 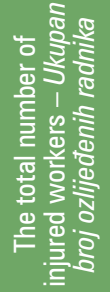 & 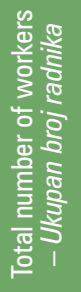 & 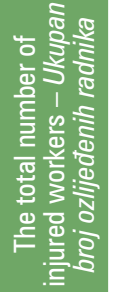 \\
\hline Logger - Sjekač & 105 & 44 & 93 & 22 & 94 & 17 & 96 & 16 & 105 & 24 \\
\hline Silvicultural worker - Šumski radnik & 132 & 8 & 125 & 4 & 122 & 10 & 122 & 11 & 110 & 4 \\
\hline Manual loader - Utovarač prostornog drveta (ručno) & 15 & 1 & 17 & 4 & 22 & 0 & 24 & 0 & 26 & 0 \\
\hline Truck driver - Vozač kamiona & & 2 & 68 & 0 & 64 & 0 & 64 & 0 & 63 & 0 \\
\hline Tractor driver - Vozač traktora & 71 & 2 & 68 & 1 & 64 & 4 & 64 & 5 & b3 & 2 \\
\hline Sum - Suma & 323 & 57 & 302 & 31 & 301 & 31 & 306 & 32 & 303 & 30 \\
\hline
\end{tabular}




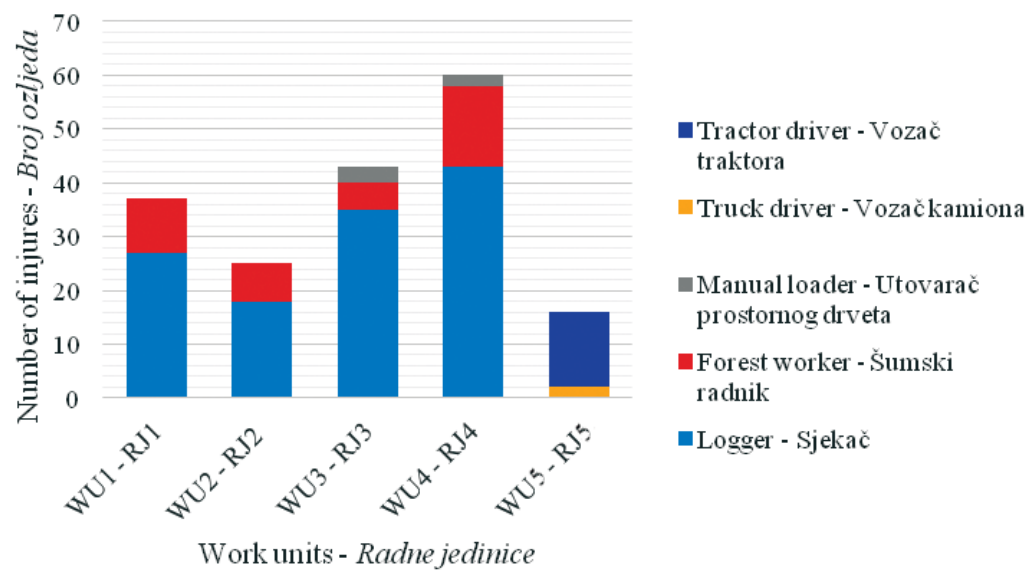

Figure 3: Distribution of the number of injuries by work units and workplaces

Slika 3: Distribucija broja ozljeda po radnim jedinicama i poslovima

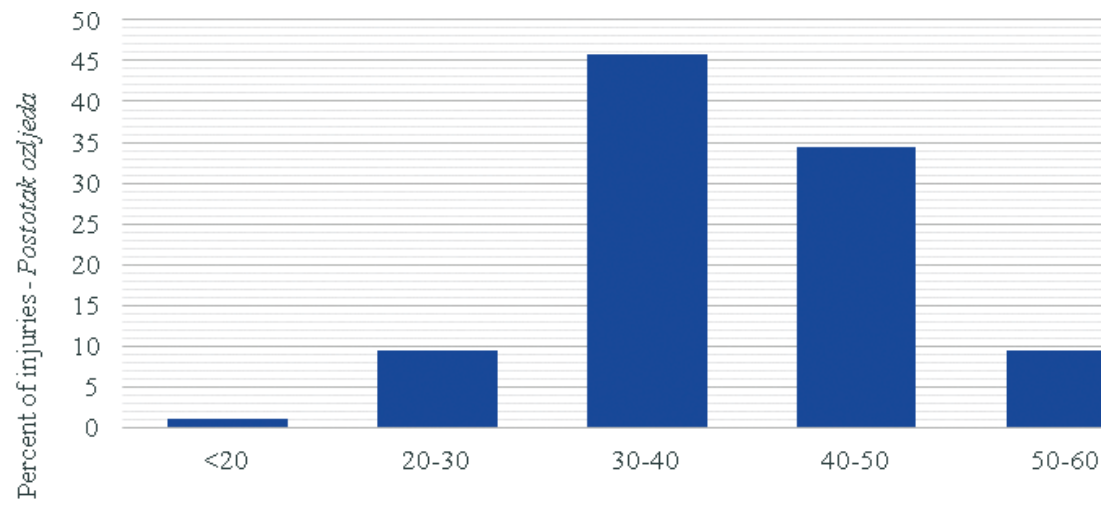

Age of workers - Starost radnika

Figure 4. Percentage of injured loggers by age

Slika 4. Postotak ozljeda sjekača prema starosnoj dobi

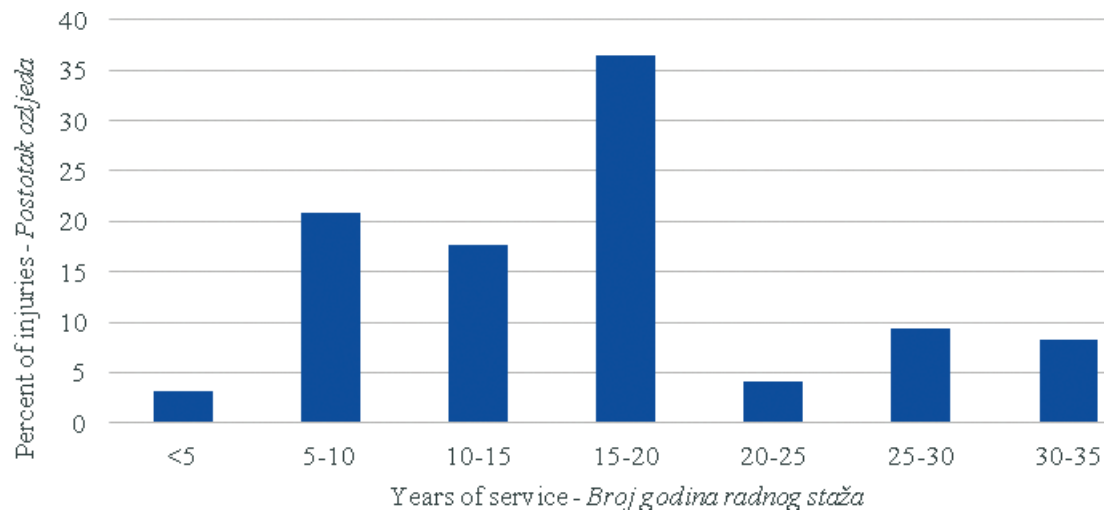

Figure 5. Percentage of injured loggers by length of service

Slika 5. Postotak ozlijeđenih sjekača prema broju godina radnog staža

The largest number of logger injuries occurred in March and May (Figure 6), which can be explained by the heaviest workload in these months. As far as weekdays are concerned, the largest number of injuries occurred on Monday (almost 1/3 of injuries) (Figure 7).
Some injuries occurred on Saturday, because the workers' work was measured by performance and not strictly related to workdays. The largest number of injuries took place in the period from 10 to $11 \mathrm{~h}$ in the morning (Figure 8). The reason for such a large number of injuries can be found in 


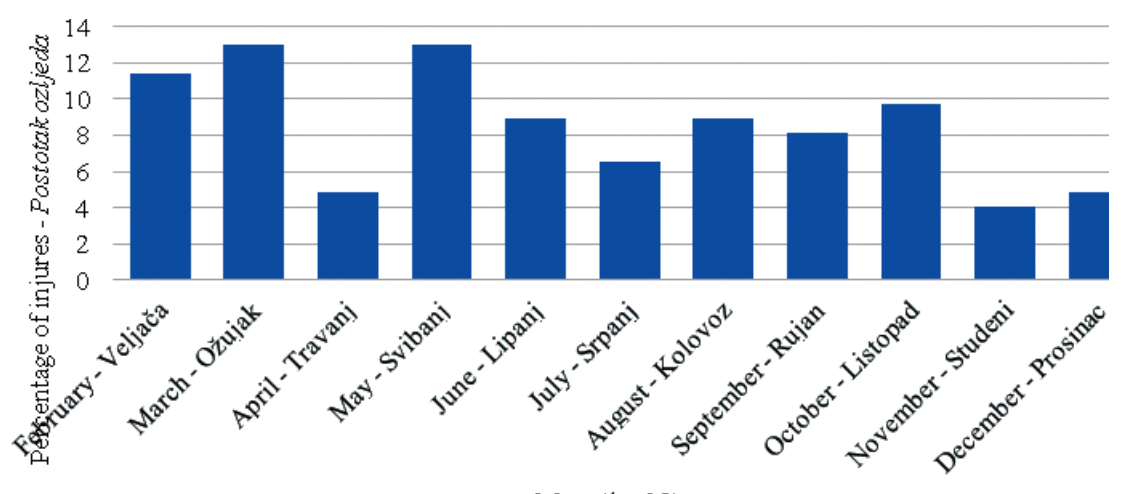

Mounth - Mjesec

Figure 6: Distribution of injuries by months

Slika 6: Distribucija ozljeda po mjesecima

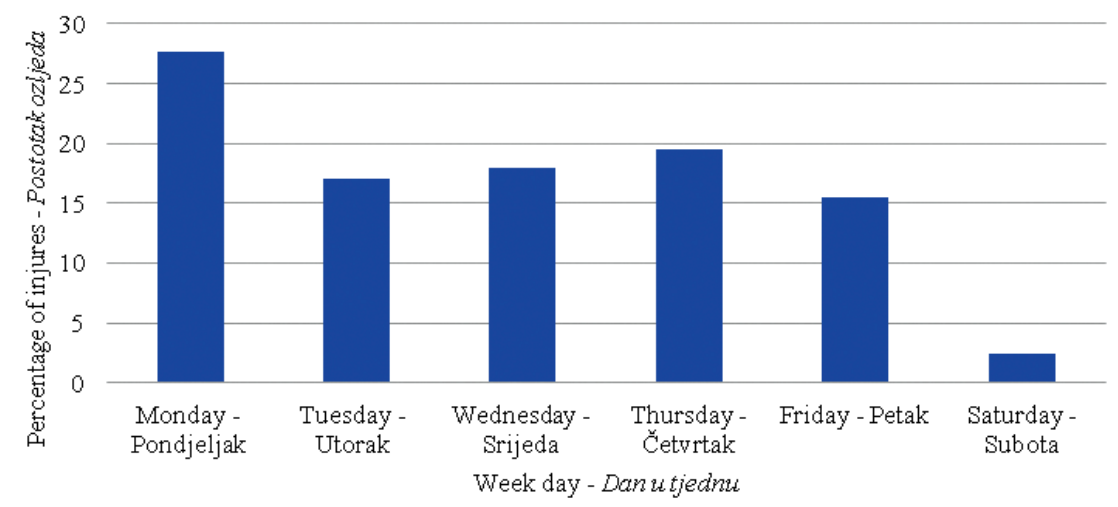

Figure 7: Distribution of injuries by days

Slika 7: Distribucija ozljeda po danima

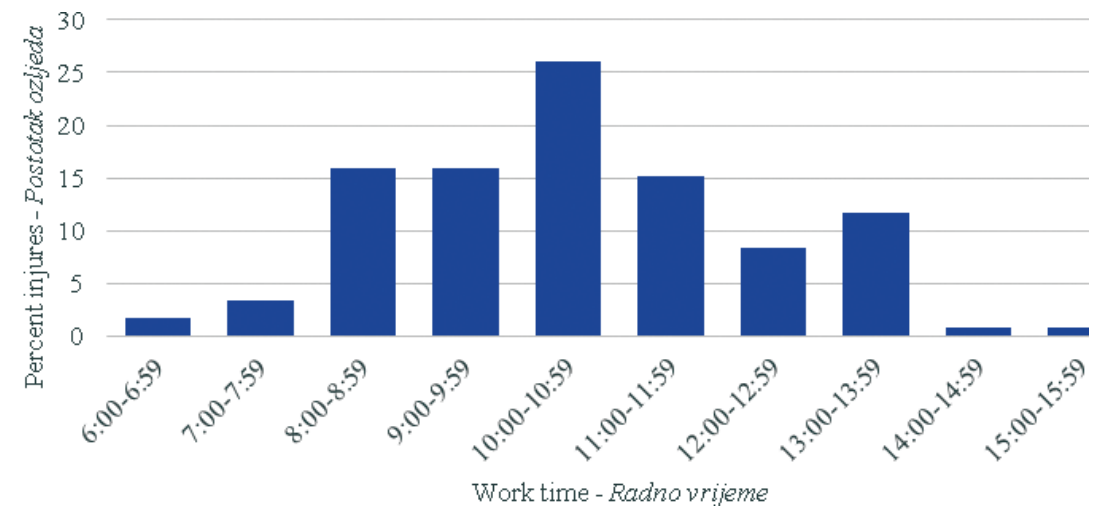

Figure 8: Distrubution of the number of injuries during work time

Slika 8: Distribucija broja ozljeda tijekom radnog vremena

the fact that workers usually take a break for breakfast in the period from 09:30 to 10:00 h. They relax after breakfast and continue with their work under reduced concentration, which results in injuries.

The most commonly injured body parts were the legs and arms (Figure 9). The most common cause of the injury was the blow of a branch (35\%), which is followed by injuries caused by the chainsaw chain (21\%) (Figure 10).
When logging and assortment processing in the 2008-2012 period is concerned, it was established that the average number of workdays achieved by injured hardwood loggers was 228.7 days, while the number of days spent for the logging of soft broadleaves was 53. The reason for this was the engagement of harvesters in poplar plantations. However, the average volume of hardwoods logged by the workers was $501.8 \mathrm{~m}^{3}$, while the average volume of soft broadleaves rea- 


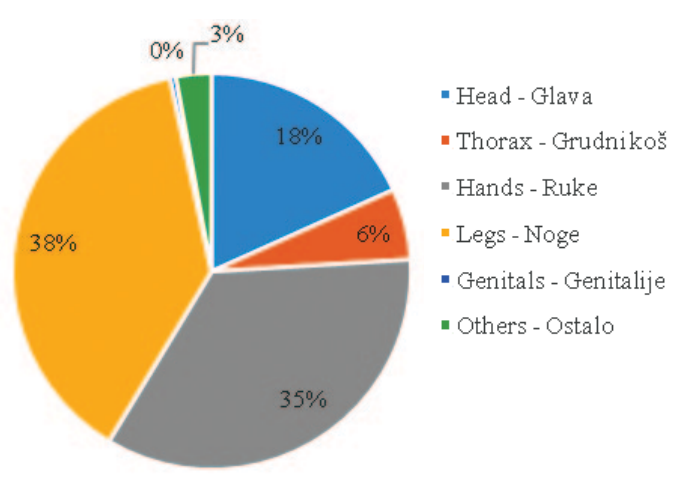

Figure 9: Display of injuries by body parts

Slika 9: Prikaz ozljeda prema lokalizaciji ozljede

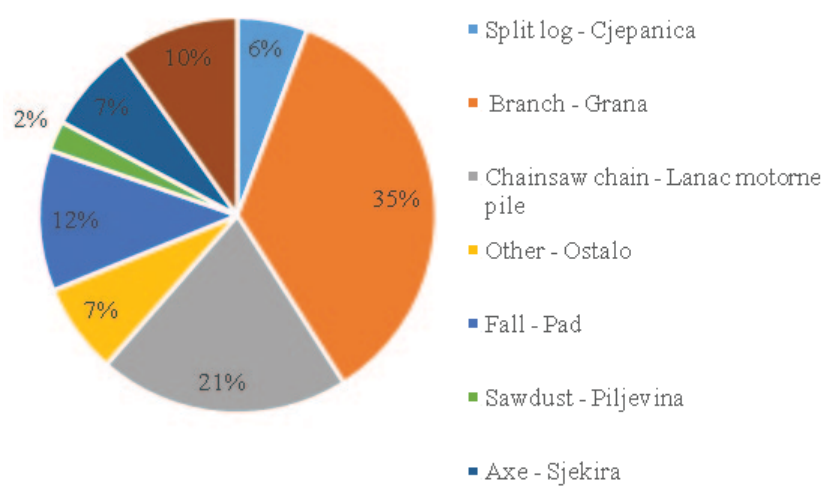

Figure 10: Display of injuries by cause of injury Slika 10: Prikaz ozljede prema uzroku ozljede

ched $706.1 \mathrm{~m}^{3}$ in one year. Thus, workers spent about 4 times more time on the logging of hardwoods, but on average the realized performance was smaller by nearly $30 \%$.

There is a certain dependence between the percentage share of injured loggers in the total number of workers and an increase in the coefficient of norm enhancement in comparison to the prescribed work norm for the operating conditions in which the loggers worked ( $\mathrm{r}-0.85, \mathrm{Sr}-0.0086)$, where are $\mathrm{r}$ - correlation coefficient and $\mathrm{Sr}$ - standard error. This relationship can be represented by the function $R_{p}=\frac{1}{(0,596-0,459 \cdot k)}$.

$\left(R_{\mathrm{p}}-\right.$ percentage share of injured loggers in the total number of loggers, $\mathrm{k}$ - coefficient of norm enhancement in comparison to the norms prescribed for the operating conditions).

The data used for calculating the dependence were taken as average annual values. Other factors were considered constant, i.e. their impact was not analyzed.

\section{DISCUSSION AND CONCLUSIONS} RASPRAVA I ZAKLJUČCI

In spite of technological advances, forestry work continues to be one of the most dangerous activities, in particular when the workers do not have adequate training (Klun and Medved, 2007). In many states, certified or licensed logger programs only require approximately $4-8$ hours of training in safe work practices (primarily chainsawing). Few, if any, of these programs have been rigorously evaluated in a quantitative manner to assess their ability to reduce injury (Bell and Grushecky, 2006). In general, even in other industries, there are relatively few examples of studies that have quantified injury reductions after training (Johnston, et al. 1994). Forest work is characterized by its seasonality, in the majority of companies most workers are not permanently employed. In Italy, $60 \%$ of forest firms are seasonal (Picchio et al., 2010). Because of poor management, workers' low level of education, and lack of resources, safety is often neglected in many Chinese logging operations (Wang et al., 2003). However, a specific feature of this study is that all workers have undergone previous training composed of a theoretical and practical part. In addition, while in other studies a large number of workers were employed only seasonally, most workers engaged in forest utilization in this study are permanently employed. In spite of the training, the share of injured loggers in the total number of loggers is $25 \%$. The largest number of injuries occurred in 2008 , with a $77 \%$ share of loggers in the total number of injured workers.

Fortunately, there were no fatal injuries in the investigated period. The incidence of fatal work accidents is fluctuating (Suchomel et al., 2013). With an estimated lifetime fatality risk of 62.7 per 1,000 full-time workers, it is well documented that logging is one of the most hazardous occupations (Fosbroke, et al., 1997; Leigh, 1987; Marshall et al., 1994; Myers et al., 1994). Amongst the causes of fatal accidents are: falling trees, accidents with vehicles and accidents with work equipment (OSHA, 2008). Falling trees were associated with many fatal accidents as well as with accidents that resulted in severe non-fatal injuries (Lindroos and Burström, 2010). According to the official data (Šporčić and Sabo, 2002) in the 1994-1999 period an annual of 625 occupational injuries occurred in Croatian forests, while the number of fatal injuries ranged from 0 to 7 . According to data from 2010 (Landekić) forestry (together with agriculture and fishery) with 7.95 occupational injuries in 1000 workers was among the least harmful occupations, as a significantly higher number of injuries was recorded in processing (18.47), and supply of electricity, gas and water (14.38) and construction (14.32).

However, the main causes of logger injuries that stand out are the blow of a branch (35\%) and chainsaw chain (21\%).

The average worker age in this study was 38.8 , which is similar to the situation in Australia 39 years (Driscol et al., 1995) and Ireland 40 years (Nieuwenhuis and Lyons, 2002). The oldest age of workers was recorded in Sweden, where 
the average age of those killed in forestry labour accidents is 60 years (Lindroos and Burströmb, 2010), and the youngest age was recorded in China, where two thirds of those killed were under 25 (Wang et al., 2003).

Physical or dangerous jobs are less and less attractive for young Europeans (Blombäck et al., 2003). A significant correlation was found between the lack of worker experience and high accident rate (Wang et al., 2003; Bentley et al., 2002; Shaffer and Milburn, 1999; Lefort et al., 2003). Some authors find a coincidence in a higher rate for younger and older people (Wilhelmson et al., 2005; Neely and Wilhemson, 2006), while other studies did not detect significant differences (Salminen et al.,1999). The average length of service of the injured workers was 16 years, similar as Nieuwenhuis and Lyons (2002) found a low accident rate in Ireland due to the experience of workers, which was on average 11.5 years.

Low exposure times might statistically imply low accident probabilities, but have also been argued to increase accident rates per unit time worked due to a lack of practice in handling the seldom-encountered risks (Elvik, 2006; Fischer et al., 2005; Weegels and Kanis, 2000). Approximately 33\% of the total nonfatal logging injuries and $29 \%$ of fatalities occurred to workers with less than 1 year of employment, while $48 \%$ of nonfatal and fatal injuries involved workers with less than 3 years of employment (Wang et al., 2003).

The workers with very little experience are less aware of the risks that they take, being more prone to injury (Tobisch et al., 2005) except slipping, tripping over and falls, which are more frequent among those of greater experience (Bentley et al., 2002). Not only accidents but also injuries to the lumbar region, shoulders and neck are related to a higher age group (Hagen et al., 1998).

Our study has shown that the most commonly injured body parts are the legs and arms (73\%), while head injuries account for $18 \%$. The likelihood of an employee suffering from an accident during the working year is correlated with the handling of chainsaws, the use of hookaroons, smoking, the number of breaks taken while working, experience, shoulder and knee height, leg and arm length and hand and foot width (Korhan et al., 2014).

In this study the largest number of injuries occurred in March and May, whereas a research from China in Jilin has shown that most injuries occurred from November to March (Wang, et al. 2003).

The largest number of injuries occurred in the period between 10 and 11 a.m. (26\%). The research Wang et al. (2003) shows slightly different results, i.e. that the first peak occurred between 9:00 and 9:59 a.m. (15.1\%) and the second peak between 3:00 and 3:59 p.m. (12.6\% of the total number). All fatalities occurred within the time frame from
7:00 to 7:00 p.m. and followed the same pattern as nonfatal injuries with two peaks at 9:00-9:59 a.m. and 3:00-3:59 p.m.

This paper does not consider the number of sick leave days and direct worker insurance expenses. This is one of the most significant segments to be explored in the future period, because it is based on the assessment of data concerning some EU State Members. The total direct costs for insurance schemes covering accidents at work (viz. costs of medical care, daily allowances and present and future compensation for cases of permanent disability and death) have been estimated at 20 billion euros per year in the EU (EUROSTAT, 2002). It is divided up almost equally between the cost of the short-term effects of accidents (viz. medical expenses and daily allowances) and that of the long-term effects of more serious cases (viz. permanent disability and death) (Macedo and Silva, 2005). Andreoni (1986) presented quantitative evidence that prevention of occupational accidents, injuries and illnesses will reduce faults and stops of production cycles, and hence the overall production costs; his work was referred to in a program established by the European Agency for Health and Safety at Work.

In conclusions can be reached on the basis of the obtained results:

- Out of the total number of workers engaged in forest utilization, over a period of 5 years, every fourth worker was injured at least once in this period;

- The most commonly injured workers were loggers, despite the fact that FE „Sremska Mitrovica“ provided them with previous training;

- Most of the injuries occurred in March and May, on Mondays, and in the period from 10 to 11 a.m.;

- In the coming period, new evidention forms should be crated and recommendations provided in order to create a database and facilitate the analysis of occupational injuries in forestry in the territory of the PE „Vojvodinašume" and the whole territory of Serbia in the future period.

\section{REFERENCE}

\section{LITERATURA}

- Albizu-Urionabarrenetxea, P., E. Tolosana-Esteban, E. RomanJordan, 2013: Safety and health in forest harvesting operations. Diagnosis and preventive actions. A review. International Labour Office Geneva, 118 p.

- Andreoni, D., 1986: The cost of occupational accidents and diseases, occupational safety and health series, International Labour Office Geneva, No. 54.

- Arandelović, M., J. Jovanovic, 2009: Medicina rada, Medicinski fakultet Univerziteta u Nišu, 275.str., Niš

- Bell, J. L., S. Gruschecky, 2006: Evaluating the effectiveness of a logger safety training program. Journal of Safety Research, 37: $53-61$ 
- Bell, J.L., 2002: Changes in logging injury rates associated with use of feller-bunchers in West Virginia. Journal of Safety Research, 33(4): 463-471

- Bentley, T., R. Parker, L. Ashby, D, Moore, D. Tappin, 2002: The role of the New Zealand forest industry injury surveillance system in a strategic ergonomics, safety and health research programme. Applied Ergonomics, 33: 395-403

- Blombäck, P., P. Poschen, M. Lövgren, 2003: Employment Trends and Prospects in the European Forest Sector. Geneva Timber and Forest Discussion Papers, European Forest Sector Outlook Study (EFSOS), United Nations

- Cabeças, J. M., 2007: An approach to health and safety in E.U. forestry operations - Hazards and preventive measures. Enterprise and Work Innovation Studies 3: 19-31

- Danilović, M., N. Ćuprić, 2011: The state of forests in Serbia in terms of their utilization, First Serbian forestry congress-Future with forests, 11 - 13 November 2010, Belgrade.180-190

- Elvik, R., 2006: Laws of accident causation. Accident Analysis \& Prevention 38(4): 742-747

- EUROSTAT - European Commission, Guidance on work-related stress: spice of life or kiss of death, European Communities, Luxembourg, European Communities, 2002

- Fischer, V., N. Young, C. Mueller, D. T. Stueland, 2005: Three times the injuries among occasional wood cutters compared to professional loggers: sample of emergency rooms in central and northern Wisconsin. American Journal of Industrial Medicine 47(3):246-253.

- Fosbroke, D.E., S.M. Kisner, J.R. Myers, 1997: Working lifetime risk of occupational fatal injury. American Journal of Industrial Medicine, 31:459-467

- Hagen, K.B., P. Magnus, K. Vetlesen, 1998: Neck/shoulder and low-back disorders in the forestry industry: relationship to work tasks and perceived psychosocial job stress. Ergonomics, 41: $1510-1518$

- Johnston, J. J., C. Gwendolyn, J.W. Collins: 1994: The efficacy of training for occupational injury control. Occupational medicine (Philadelphia, Pa.) 9(2):147-58

- Klun, J., M. Medved 2007: Fatal accidents in forestry in some European countries. Croatian Journal of Forest Engineering, 28(1): 55-62

- Korhan, E., M. Topbas, H. A. Hulusi, 2014: An evaluation of the occupational accidents among logging workers within the boundaries of Trabzon Forestry Directorate, Turkey, International Journal of Industrial Ergonomics 44(5):621-628

- Landekić, M., 2010:. Organizacijska kultura i sigurnost pri radu u hrvatskom šumarskom sektoru, Šumarski list br. 11-12, CXXXIV: 613-622

- Lefort, A.J., de C.P. Hoop, J.C. Pine, 2003: Characteristics of injuries in the logging industry of Louisiana, USA: 1986 to 1998. International Journal of Forest Engineering. 14: 75-89

- Leigh, J.P. 1987: Estimates of the probability of job-related deaths in 347 occupations. Journal of Occupational Medicine, 29: 510519

- Lindroos, O., L. Burströmb, 2010: Accident rates and types among self-employed private forest owners. Accident Analysis and Prevention 42: 1729-1735

- Macedo, A., I. Silva. 2005: Analysis of occupational accidents in Portugal between 1992 and 2001. Safety Science,43(5): 269-286

- Marshall, S.W., I. Kawachi, P.C. Cryer, D. Wright, C. Slappendel, and I. Laird. 1994: The epidemiology of forestry work-related injuries in New Zealand, 1975-88: fatalities and hospitalisations. New Zealand Medical Journal, 107:434-7

- Martinić, I., 1999: Sigurnost i zdravlje šumskih radnika - poticaj za njihovo unapređenje u Hrvatskoj, Šumarski list br. 5-6, CXX1I: 201-210

- Martinić, I., M. Landekić, M. Šporčić, M. Lovrić, 2011: Hrvatsko šumarstvo na pragu EU - koliko smo spremni na području sigurnosti pri šumskom radu?. // Croatian journal of forest engineering, 32 (1):431-441

- Medarević, M., S. Banković, B. Šljukić, 2008: Sustainable forest management in Serbia - state and potentials. Bulletin of the Faculty of Forestry 97: 33-56

- Myers, J.R., D.E. Fosbroke, 1994: Logging Fatalities in the United States by region, cause of death, and other factors B 1980 through 1988. Journal of Safety Research, 25:97-105

- Neely, G., E. Wilhelmson, 2006:Self-reported incidents, accidents, and use of protective gear among small-scale forestry workers in Sweden. Safety Science, 44: 723-732

- Nieuwenhuis, M., M. Lyons, 2002: Health and Safety Issues and Perception of Forest Harvesting Contractors in Ireland. International Journal of Forest Engineering, 13(2): 69-76

- Official Gazette of RS, no. 101/2005

- OSHA - European Agency for Safety and Health at Work, Facts No 9: Inventory of socioeconomic information about work-related musculoskeletal disorders in the member states of the European Union, European Communities, Luxembourg, 2000

- OSHA - European Agency for Safety and Health at Work: Occupational safety and health in Europe's forestry industry, 2008

- Peters, P., 1991: Chainsaw Felling Fatal Accidents. Transactions of the ASAE 6: 2600-2608. http://dx.doi.org/10.13031/2013.31912

- Picchio, R., S. Blasi, A. Sirna, 2010: Survey on Mechanization and Safety Evolution in Forest Works in Italy.International Conference Ragusa SHWA2010. September 16-18. Proceedings 173180

- Salminen, S., T. Klen, K. Ojanen, 1999: Risk taking and accident frequency among Finnish forestry workers. Safety Science, 33: 143-153

- Shaffer, R., J. Milburn, 1999: Injuries on Feller-Buncher/Grapple Skidder Logging operations in the South-Eastern United States. Forest Products Journal, 49(7-8): 24-26

- Šporčić, M., A. Sabo, 2002: Ozljeđivanje radnika u hrvatskom šumarstvu tijekom razdoblja 1991-2000, Šumarski list br. 5-6, CXXV1: 261-271

- Suchomel, J., K. Belanová, M. Vlčková, 2013: Analysis of Work Accidents in Selected Activities in Slovakia, Czech Republic and Austria, Croatian Journal of Forest Engineering, 34(2): 312-320

- Tobisch, R., M. Walker, G. Weise, 2005:Scientific review of forest machine technical ergonomics, in Lewark S (Ed.): Scientific reviews of ergonomic situation in mechanized forest operations. Inst. för skogens produkter och marknader, Sveriges antbruksuniversitet.

- Wang, J., J.L. Bell, S.T. Grushecky, 2003: Logging injuries for a 10-year period in Jilin Province of the People's Republic of China. Journal of Safety Research, 34: 273-279

- Weegels, M. F., H. Kanis, 2000: Risk perception in consumer product use. Accident Analysis and Prevention 32(3): 365-370

- Wilhelmson, E., D. StaalWästerlund, L. Burström, P-O. Bylund, 2005: Public health effects of accidents in selfemployed forestry work. Small-Scale Forestry 4(4): 427-436 


\section{SAŽETAK}

Šumarstvo je jedna od gospodarskih grana gdje je stopa ozljeda na radu među najvećima. Uprkos tomu što se poslovi u šumarstvu uglavnom karakteriziraju sezonalnošću, a ne stalnom zaposlenošću radnika, šumsko gospodarstvo „Sremska Mitrovica“ gdje su provedena istraživanja ima drukčiju praksu. Cjelokupna sječa i izrada na području ovoga gospodarstva obavlja se ulaganjem vlastitih sredstava i vlastite radne snage. Ovo gospodarstvo karakterizira ravničarski teren s prosječnim nadmorskim visinama ispod $100 \mathrm{~m}$, gdje glavne vrste drveća čine euroamerička topola, lužnjak i jasen. Godišnji etat šumskog gospodarstva iznosi oko $200000.00 \mathrm{~m}^{3}$. U ovome radu prikazani su rezultati istraživanja broja i uzroka ozljeda na radu, za razdoblje od 5 godina (2008-2012. godine). Analizirane su samo ozljede proizvodnih šumskih radnika (sjekači, radnici koji rade na ručnom utovaru, vozači i radnici koji rade na poslovima uzgajanja šuma). Svaka ozljeda na radu evidentirana je odmah nakon što se dogodila. Klasifikacija ozljeda obavljena je na temelju Međunarodne klasifikacije bolesti (International Classification of Diseases and Related Health Problems), a korišten je šifrarnik bolesti iz odjeljka ,vanjski uzroci obolijevanja i umiranja (V01-Y98)“ (external causes of morbidity and mortality) (V01-Y98)). Nakon svake evidentirane ozljede na radu, medicina rada je slala Izveštaj o liječničkom pregledu ozlijeđenog radnika Republičkoj inspekciji rada, Ministarstvu unutrašnjih poslova i referentu zaštite na radu u radnoj jedinici gdje je radnik bio zaposlen. Iz Izveštaja o liječničkom pregledu zaposlenog podaci su unošeni u posebnu evidenciju. Ocjenu težine ozljede davao je liječnik koji je prvi pregledao zaposlenog. Radnicima koji su radili kao sjekači, šumsko gospodarstvo osiguralo je tečaj koji je trajao mjesec dana (teorijska nastava) i dva mjeseca praktične obuke, gdje su sjekači obavili sječu i obaranje uz pomoć iskusnijeg kolege (mentora).

Ukupan broj radnika koji je na godišnjoj razini bio zaposlen na poslovima korištenja šuma kretao se od 302 (2010. godine) do 323 (2008. godine) (Tablica 1). Najveći broj radnika bio je zaposlen na poslovima uzgajanja šuma. Na temelju analize broja ozljeda na radu u razdoblju od 2000-2012. godine utvrđeno je da je najveći broj ozljeda na radu zabilježen kod radnika koji su radili kao sjekači (Slika 2). Ukupan broj ozljeda koji je evidentiran u razdoblju 2008-2012. godine je bio 181, gdje su 172 ozljede evidentirane kao lake, dok je 9 ozljeda kategorizirano kao teška tjelesna ozljeda. Od ukupnog broja ozlijeđenih radnika, najveći postotak čine radnici koji su obavljali posao sjekača (68\%), zatim posao radnika koji su radili na poslovima uzgajanja šuma $(20 \%)$, vozača traktora $(8 \%)$, radnici koji rade na ručnom utovaru $(3 \%)$ i vozača kamiona (1\%) (slika 3$)$. Postotak ozlijeđenih sjekača u odnosu na ukupan broj iznosi $25 \%$. Najčeće su se povređivali sjekači starostne dobi između 30 i 40 godina (Slika 4), odnosno oni radnici koji su imali između 15 i 20 godina radnog staža (Slika 5). Najveći broj ozljeda sjekača dogodio se u ožujku i svibnju. Promatrajaći dane u tjednu, najveći broj ozljeda dogodio se ponedjeljkom (skoro 1/3 povreda). Najveći broj ozljeda dogodio se u razdoblju od 10-11 sati prije podne (Slika 8). Najčešće povređivan dio tijela su noge i ruke (Slika 9). Najčešći uzrok ozljede je udarac grane (35\%), zatim sljede ozljede uzrokovane lancem motorne pile (21 \%) (Slika 10). Ono što su autori ovoga članka zapazili analizirajući podatke, je činjenica da evidencije o povredama radnika postoje, ali da nisu bile uniformne ni po godinama ni po radnim jedinicama, i često su nedostajali detaljni podaci o povredi. Tako je odlučeno da se u idućem razdoblju u dogovoru s nadležnima iz JP kreiraju novi obrasci koje treba popunjavati sukladno preporukama, koji će također biti dati kao prateći materijal.

KLJUČNE RIJEČI: pridobivanje drva, ozljede na radu, ozljede sjekača 